\title{
Chromosome 14
}

National Cancer Institute

\section{Source}

National Cancer Institute. Chromosome 14. NCI Thesaurus. Code C13209.

The designation for each member of the fourteenth largest human autosomal

chromosome pair. Chromosome 14 spans about 105 million base pairs and represents between 3 and $3.5 \%$ of the total DNA in normal diploid cells. 